Article

\title{
Study on Physical Properties of Mortar for Section Restoration Using Calcium Nitrite and $\mathrm{CO}_{2}$ Nano-Bubble Water
}

\author{
Ho-jin Kim ${ }^{1}$, Hyeonggil Choi ${ }^{2, *}$, Heesup Choi ${ }^{3, *}{ }^{\circ}$, Bokyeong Lee ${ }^{4}$, Dongwoo Lee ${ }^{5}$ and \\ Dong-Eun Lee ${ }^{2}$ (D) \\ 1 Daegu Gyeongbuk Branch, Korea Testing \& Research Institute, Daegu 41516, Korea; white002@ktr.or.kr \\ 2 School of Architecture, Civil Environment and Energy Engineering, Kyungpook National University, \\ Daegu 41566, Korea; dolee@knu.ac.kr \\ 3 Department of Civil and Environmental Engineering, Kitami Institute of Technology, Hokkaido 090-8507, Japan \\ 4 Intelligent Construction Automation Center, Kyungpook National University, Daegu 41566, Korea; \\ bklee11@knu.ac.kr \\ 5 BUKUK (Neutralization \& Prevention of Structure Hazard System), Gyeonggi-do 17001, Korea; \\ hit6585@gmail.com \\ * Correspondence: hgchoi@knu.ac.kr (H.C.); hs-choi@mail.kitami-it.ac.jp (H.C.)
}

Received: 6 August 2020; Accepted: 1 September 2020; Published: 3 September 2020

\begin{abstract}
This study investigated the physical properties of section-restoration mortar with calcium nitrite $\left(\mathrm{Ca}\left(\mathrm{NO}_{2}\right)_{2}\right)$ and carbon dioxide $\left(\mathrm{CO}_{2}\right)$ nanobubble mixing water to develop materials and methods for the repair and reinforcement of cracks in reinforced concrete (RC) structures. As the calcium nitrite content increased, the generation rate and generated amount of nitrite-based hydration products also increased, owing to the rapid reaction between $\mathrm{NO}_{2}{ }^{-}$ions in calcium nitrite and $\mathrm{C}_{3} \mathrm{~A}\left(\mathrm{Al}_{2} \mathrm{O}_{3}\right)$. Further, the reaction with $\mathrm{C}_{3} \mathrm{~S}$ and $\mathrm{C}_{2} \mathrm{~S}$ was accelerated, thereby increasing the generation rates of $\mathrm{Ca}(\mathrm{OH})_{2}$ and C-S-H. The large amount of $\mathrm{Ca}^{2+}$ ions in these hydration products reacted with $\mathrm{CO}_{3}{ }^{2-}$ ions in $\mathrm{CO}_{2}$ nanobubble water, thereby increasing the generation of calcite-based $\mathrm{CaCO}_{3}$ in the cement matrix. This appears to have affected strength development and durability improvement via the densification of the structure. These results suggest that the performance of polymer cement mortar for repairing concrete structures can be improved if calcium nitrite and $\mathrm{CO}_{2}$ nanobubble water are properly combined and applied.
\end{abstract}

Keywords: calcium nitrite; $\mathrm{CO}_{2}$ nanobubble water; section restoration; mortar

\section{Introduction}

In recent years, global efforts have focused on reducing industrial carbon dioxide $\left(\mathrm{CO}_{2}\right)$ emissions. In this light, South Korea has aimed to reduce its industrial $\mathrm{CO}_{2}$ emissions. The construction industry accounts for approximately $40 \%$ of total industrial $\mathrm{CO}_{2}$ emissions [1]. Further, cement production and concrete manufacturing account for approximately $5 \%$ of these emissions. Therefore, it is essential to reduce $\mathrm{CO}_{2}$ emissions in the construction industry. One way of doing so is to properly maintain the existing structures through repair and reinforcement instead of building new structures. For this purpose, repair and reinforcement methods with reduced environmental loads must be developed for extending the service life of concrete structures.

Concrete is widely used in the construction industry. The tensile strength of concrete is significantly lower than its compressive strength. In particular, cracks inevitably occur in buildings owing to various problems in the mix design and construction process [2]. Microcracks in buildings are generally not considered significant structural problems [3]. Nonetheless, microcracks facilitate the penetration of 
chlorides and $\mathrm{CO}_{2}$ that are highly likely to critically degrade the structural stability of reinforced concrete (RC) structures [4]. Cracks in RC structures also negatively impact the appearance of these structures [5]. Therefore, crack formation must be prevented. Further, materials and methods for crack repair and reinforcement must be developed to realize high-performance RC structures and sustainable buildings.

A previous study noted that in a moist environment, concrete containing small cracks showed a self-healing phenomenon in which part of the crack was filled [6-14]. This phenomenon occurred due to the rehydration of cement particles and the precipitation of $\mathrm{CaCO}_{3}$; specifically, $\mathrm{CaCO}_{3}$ was generated by the reaction between $\mathrm{Ca}^{2+}$ in concrete and $\mathrm{CO}_{3}{ }^{2-}$ dissolved in water. Further, a strong self-healing effect was observed when $\mathrm{CO}_{2}$ nanobubble water was used [2]. Calcium nitrite $\left(\mathrm{Ca}\left(\mathrm{NO}_{2}\right)_{2}\right)$ is widely used as the main component in antifreeze admixtures. Increasing the calcium nitrite content accelerates the hydration reaction of $\mathrm{C}_{3} \mathrm{~A}$ and $\mathrm{C}_{3} \mathrm{~S}$ (both of which are components of cement) and thereby increases the generation of ettringite-based hydrate (Aft). Further, the generation of nitrite-based hydrates in large quantities owing to the reaction between $\mathrm{C}_{3} \mathrm{~A}\left(\mathrm{Al}_{2} \mathrm{O}_{3}\right)$ and $\mathrm{NO}_{2}{ }^{-}$increases the initial strength of concrete [15].

In this light, the present study investigates the physical properties of section-restoration mortar with calcium nitrite and $\mathrm{CO}_{2}$ nanobubble mixing water to develop materials and methods for the repair and reinforcement of cracks that occur in RC structures.

\section{Materials and Methods}

\subsection{Experimental Plan}

Tables 1 and 2 show the experimental plan and mortar mix proportion of this study, respectively. The design strength was set in accordance with KS F 4042 [16]. Through a preliminary mixing experiment, the water/binder ratio $(\mathrm{W} / \mathrm{M}(\mathrm{B}+\mathrm{S})$ ) was determined to be $16 \%$. Experiments were conducted by adding $0 \%, 1 \%, 3 \%$, and $5 \%$ calcium nitrite relative to the weight of cement. Ordinary tap water and $\mathrm{CO}_{2}$ nanobubble water were used as mixing water, and eight types of mortar specimens were prepared.

Table 1. Experimental plan.

\begin{tabular}{|c|c|c|}
\hline Item & & Values \\
\hline \multirow{3}{*}{ Experimental variables and level } & $\mathrm{W} / \mathrm{M}(\%)$ & 16 \\
\hline & $\mathrm{Ca}\left(\mathrm{NO}_{2}\right)_{2}$ dosage ${ }^{1}$ & $\mathrm{CN} 0 *, \mathrm{CN} 1, \mathrm{CN} 3, \mathrm{CN} 5 *$ \\
\hline & Mixing water type & Tap water (TW), Nanobubble water (NW) \\
\hline Evaluation items & $\begin{array}{ll}- & \text { Flow } \\
- & \text { Compressive s } \\
- & \text { Flexural streng } \\
- & \text { Length change } \\
- & \text { Carbonation d } \\
- & \text { Porosity } \\
- & \text { Scanning elect }\end{array}$ & $\begin{array}{l}\text { ength }(3,7,28 \text { days }) \\
(3,7,28 \text { days }) \\
\text { pth }(4,8,12 \text { days }) \\
\text { on microscopy micrograph (SEM)* }\end{array}$ \\
\hline
\end{tabular}

${ }^{1} \mathrm{CNx}: \mathrm{x}=$ Amount of $\mathrm{Ca}\left(\mathrm{NO}_{2}\right)_{2}($ Binder $\times \mathrm{wt} \%) .{ }^{*}$ Porosity and SEM analysis were conducted only for $\mathrm{CN} 0$ and CN5.

Table 2. Mix proportion of mortar.

\begin{tabular}{|c|c|c|c|c|c|c|c|c|}
\hline \multirow[b]{2}{*}{ W/M ${ }^{1}(\%)$} & \multirow[b]{2}{*}{ B:S ${ }^{2}$} & \multicolumn{7}{|c|}{ Binder (wt\%) } \\
\hline & & Cement & CSA & Resin & $\begin{array}{l}\text { Anhydrous } \\
\text { Gypsum }\end{array}$ & $\begin{array}{l}\text { PVA } \\
\text { Fiber }\end{array}$ & Superplasticizer & $\begin{array}{c}\text { Viscosity } \\
\text { Agent }\end{array}$ \\
\hline 16 & $1: 1.45$ & 89.5 & 6.6 & 1.5 & 1.2 & 0.6 & 0.58 & 0.04 \\
\hline
\end{tabular}


The table flow, compressive strength, flexural strength, length change rate, and carbonation depth were measured. For microstructure analysis, the porosity was analyzed, and scanning electron microscopy (SEM) was conducted. The results of these experiments were used to examine whether the polymer cement mortar used for repairing concrete structures satisfied the KS F 4042 quality criteria (Table 3) [16].

Table 3. Quality criteria (KS F 4042 [16]).

\begin{tabular}{cc}
\hline Evaluation Items & Quality Criteria \\
\hline Compressive strength $\left(\mathrm{N} / \mathrm{mm}^{2}\right)$ & More than 6.0 \\
\hline Flexural strength $\left(\mathrm{N} / \mathrm{mm}^{2}\right)$ & More than 20.0 \\
\hline Carbonation depth $(\mathrm{mm})$ & More than 2.0 \\
\hline
\end{tabular}

\subsection{Materials and $\mathrm{CO}_{2}$ Nanobubble Water}

\subsubsection{Materials}

Polymer cement mortar, in which an expansive admixture and polyvinyl alcohol (PVA) fibers were premixed as repair/reinforcement materials, was used in the experiments. Ordinary tap water (temperature: $20^{\circ} \mathrm{C}$, no impurities) and $\mathrm{CO}_{2}$ nanobubble water (particle diameter $\sim 50 \mathrm{~nm}, \mathrm{pH}$ adjusted to $\sim 4.5$ (slightly acidic)) produced using a nanobubble device (HACK FB11, Tokyo, Japan) were used as mixing water.

\subsubsection{Equipment and Process to Generate $\mathrm{CO}_{2}$ Nanobubble Water}

Figure 1 shows the equipment and process used to generate $\mathrm{CO}_{2}$ nanobubble water. A nanobubble generator connected to a $\mathrm{CO}_{2}$ source was operated in a water tank filled with tap water. The gas pump generated a negative pressure to pressurize the mixing header. $\mathrm{CO}_{2}$ saturation nanobubbles (particle diameter $\sim 50 \mathrm{~nm}, \mathrm{pH}$ adjusted to $\sim 4.5$ (slightly acidic)) generated by cavitation were then discharged through the foam nozzle into the water tank to produce $\mathrm{CO}_{2}$ nanobubble water $[17,18]$. These nanobubbles generally have small buoyancy and negative surface charges on the order of tens of microvolts; therefore, they repel and do not easily stick to each other, consequently lasting for a longer duration in water than microbubbles [19].

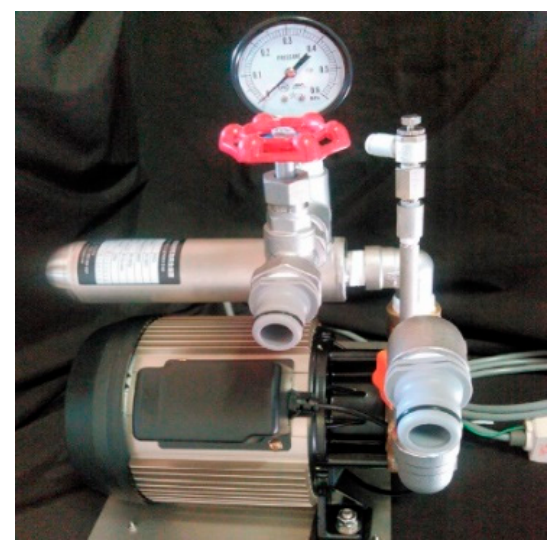

(a)

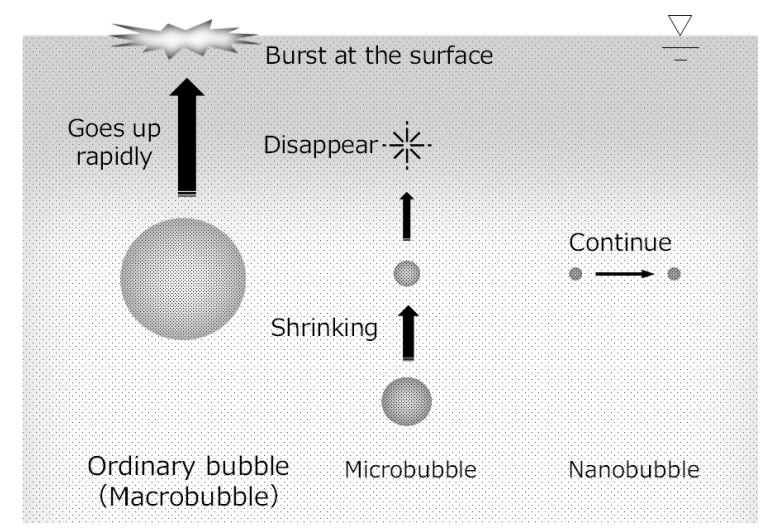

(b)

Figure 1. Equipment and process used to generate $\mathrm{CO}_{2}$ nanobubbles. (a) Depiction of the nanobubble device; (b) behavior of nanobubbles in water.

\subsection{Experimental Parameters}

In this study, the flow test was conducted to determine the workability of polymer cement mortar for repairing concrete structures. Physical properties such as strength, length change rate, 
and carbonation depth were tested to evaluate quality performances like densification and shrinkage behavior of the repair material, including calcium nitrite and $\mathrm{CO}_{2}$ nanobubbles as a mixing water. The porosity was analyzed to clarify the cause of densification through the change of the pore volume in each case over time. In addition, SEM analysis was performed to clarify the type and size of hydration products caused by the densification of the structure.

\subsubsection{Flow}

For the flow of mortar (a non-hardening property) the experimental flow table of KS L 5111 [20] was used. The flow was measured immediately as well as 30 and $60 \mathrm{~min}$ after mixing in proportion with KS F 2476 [21].

\subsubsection{Compressive and Flexural Strength}

Prismatic mortar specimens with a size of $40 \times 40 \times 160 \mathrm{~mm}$ were fabricated for the strength test in accordance with KS F 4042 [16]. They were demolded at two days of age and subjected to standard water curing at $20^{\circ} \mathrm{C}$. Their flexural strength was measured at 3,7 , and 28 days of age by using the central loading method and a universal testing machine (UH-F1000 kNX, Shimadzu, Kyoto, Japan) in accordance with KS F 2408 [22]. To test the compressive strength, specimens that were fractured after measuring their flexural strength were used. After mounting the specimens in a compression mold $(40 \times 40 \times 40 \mathrm{~mm})$, the compressive strength was measured at 3, 7, and 28 days of age in accordance with KS F 2405 [23]. Figure 2 shows the setup for measuring the compressive and flexural strengths.

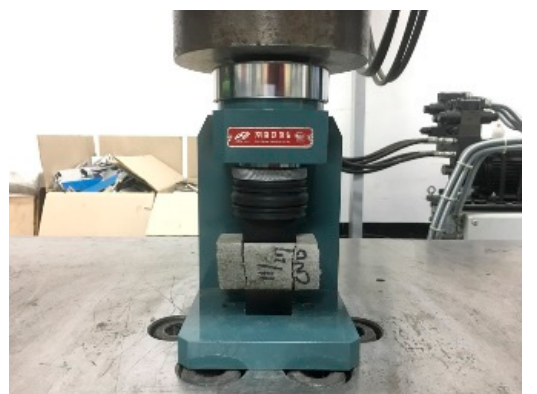

(a)

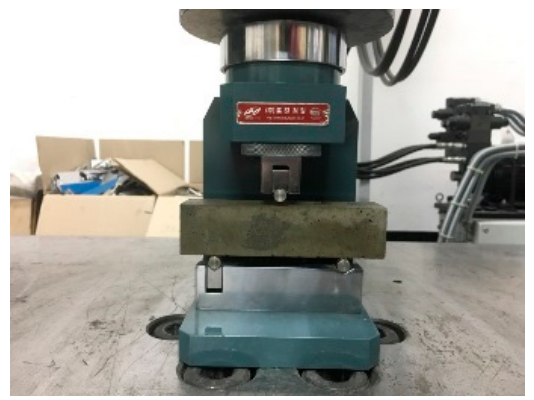

(b)

Figure 2. Pictures of the strength tests, with (a) the compressive strength test and (b) the flexural strength test.

\subsubsection{Length Change Rate}

Prismatic mortar specimens $(40 \times 40 \times 160 \mathrm{~mm})$ in accordance with KS F 4042 [16] were used to test the length change rate. The specimens were demolded at two days of age and subjected to water curing at $(20 \pm 3)^{\circ} \mathrm{C}$ for five days. They were then cured in a constant temperature and humidity chamber at $(20 \pm 3){ }^{\circ} \mathrm{C}$ and $(60 \pm 5) \% \mathrm{RH}$. The length change rate was measured for predetermined ages by using the dial gauge method of KS F 2424 [24].

\subsubsection{Carbonation Depth}

The carbonation depth was measured by the accelerated carbonation test of KS F 2596 [25]. The acceleration conditions were at a temperature of $(20 \pm 2){ }^{\circ} \mathrm{C}$, a humidity of $(60 \pm 5) \%$, and a $\mathrm{CO}_{2}$ concentration of $(5 \pm 0.2) \%$. The specimens were sealed with aluminum tape except at the top surface to block the infiltration of $\mathrm{CO}_{2}$. A solution of $1 \%$ phenolphthalein was sprayed on the split specimens, and the depth of the part that turned red was measured at $10 \mathrm{~mm}$ intervals by using a Vernier caliper. 


\subsubsection{Porosity and SEM Analysis}

Porosity measurements and SEM analysis were conducted only for specimens with $0 \%$ and $5 \%$ calcium nitrite to investigate the properties of tap water and $\mathrm{CO}_{2}$ nanobubble water according to the calcium nitrite content.

As shown in Figure 3, samples were collected from the specimens fractured after measuring the strength at 3 and 28 days of age. The collected samples were used in the experiment after being immersed in acetone for more than four hours to stop the hydration reaction.

The samples used for porosity measurements were oven-dried at $60{ }^{\circ} \mathrm{C}$. Mercury was then pressurized at 0-60,000 psi by using a porosity analyzer (AutoPore IV 9520, Norcross, GA, USA), and the pore size and cumulative pore volume of each specimen were measured from the amount of penetration. SEM analysis was conducted using the SNE-3200M device (SEC, Suwon, Korea), and the collected powder-type samples were coated with platinum. They were then observed at $3000 \times$ magnification at an acceleration voltage of $15 \mathrm{kV}$.

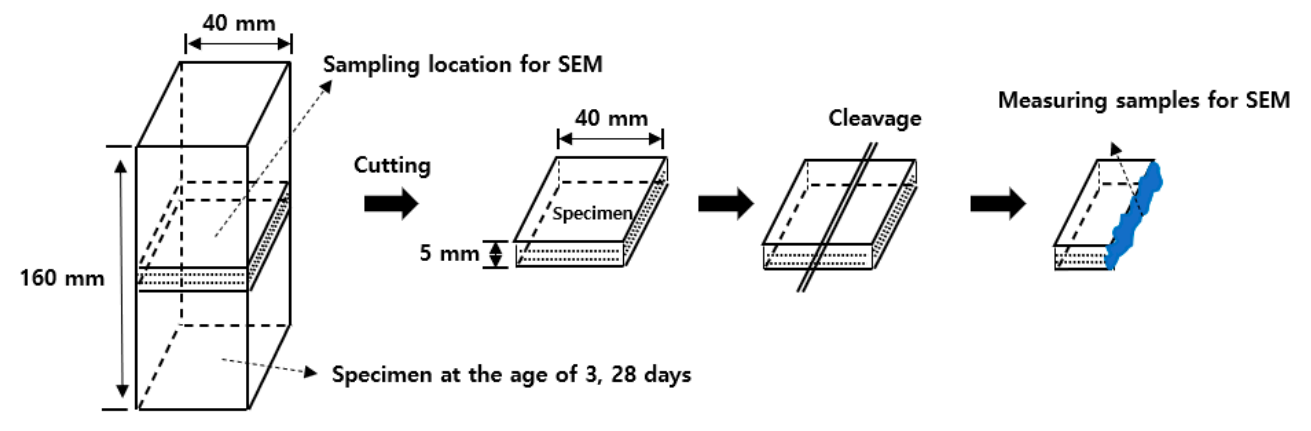

Figure 3. Specimen sampling for SEM.

\section{Results and Discussion}

\subsection{Flow}

Figure 4 shows the flow test results. Regardless of whether tap water or $\mathrm{CO}_{2}$ nanobubble water was used, specimens with calcium nitrite tended to show high flow values. The flow did not seem to show any relation to the type of mixing water or the calcium nitrite content.

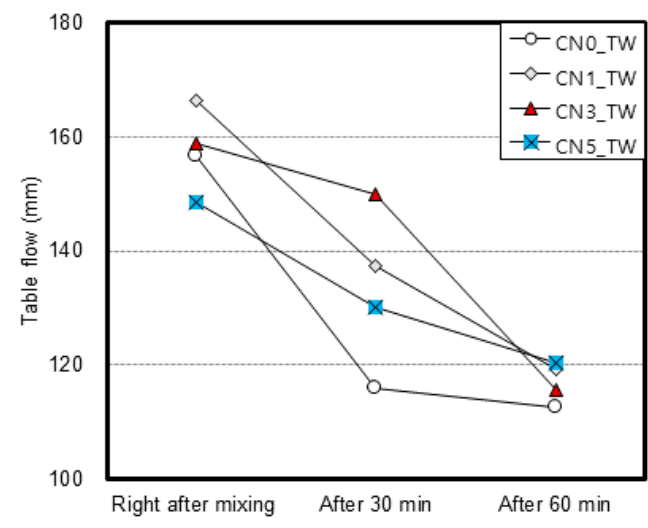

(a)

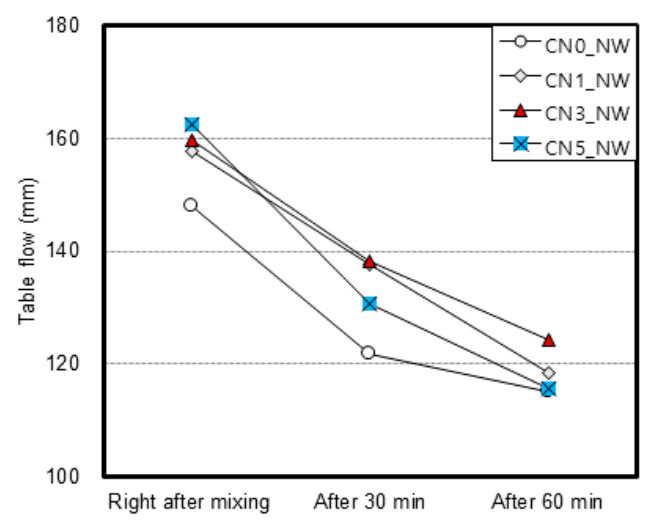

(b)

Figure 4. Flow test results: (a) result with tap water; (b) result with nanobubble water.

\subsection{Compressive and Flexural Strength}

Figures 5 and 6 show the compressive and flexural strength results of the specimens when using tap water and $\mathrm{CO}_{2}$ nanobubble water according to the calcium nitrite content and age. For both types of mixing water, the compressive and flexural strengths increased with an increase in the calcium nitrite 
content. This was because $\mathrm{NO}_{2}{ }^{-}$ions in calcium nitrite rapidly reacted with $\mathrm{C}_{3} \mathrm{~A}\left(\mathrm{Al}_{2} \mathrm{O}_{3}\right)$, a component of cement, to increase the generation rate and amount of nitrite-based hydration products [26]. The $\mathrm{CN} 0$ specimen with $\mathrm{CO}_{2}$ nanobubble water showed somewhat higher compressive and flexural strengths because this water was initially produced at $30^{\circ} \mathrm{C}$, which was higher than the temperature for other specimens.

A comparison of the compressive and flexural strength results with the use of tap water and $\mathrm{CO}_{2}$ nanobubble water revealed a larger strength improvement effect with the latter. This result was similar to a previously reported result on the compressive strength of cement mortar using $\mathrm{CO}_{2}$ nanobubble water [27]. It seemed attributable to the increased generation of calcite-based $\mathrm{CaCO}_{3}$ in the cement matrix, as a large amount of $\mathrm{Ca}^{2+}$ ions was generated through the aforementioned accelerated the reaction between calcium nitrite, and cement reacted with the $\mathrm{CO}_{3}{ }^{2-}$ ions in the $\mathrm{CO}_{2}$ nanobubble water. This led to strength improvement via the densification of the structure [28-30].

For calcium nitrite content of $3 \%$ or higher, both the compressive and the flexural strengths satisfied the quality criteria of 20 and $6 \mathrm{MPa}$, respectively, specified in KS F 4042 [16] regarding the compressive and flexural strengths of polymer cement mortar required to repair concrete structures.

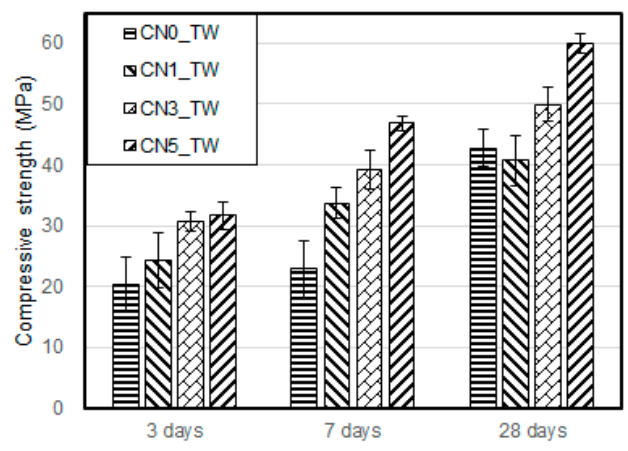

(a)

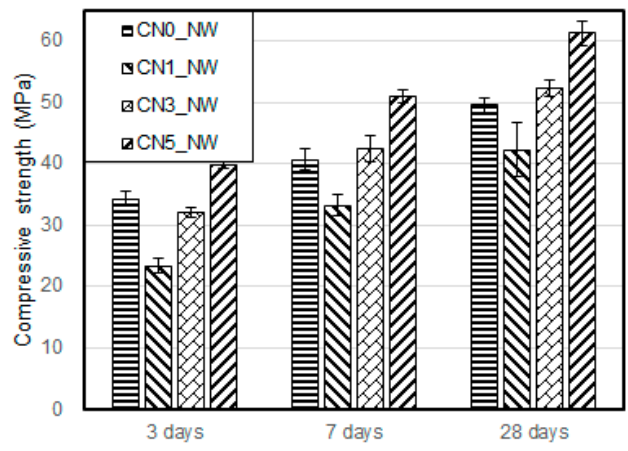

(b)

Figure 5. Compressive strength test results: (a) result with tap water; (b) result with nanobubble water.

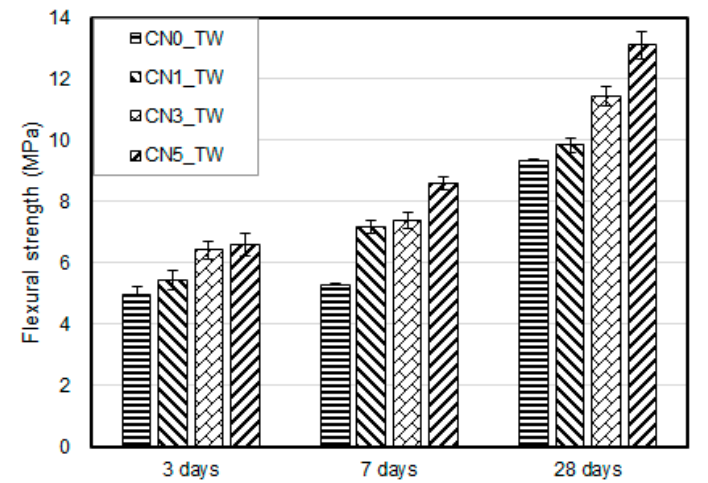

(a)

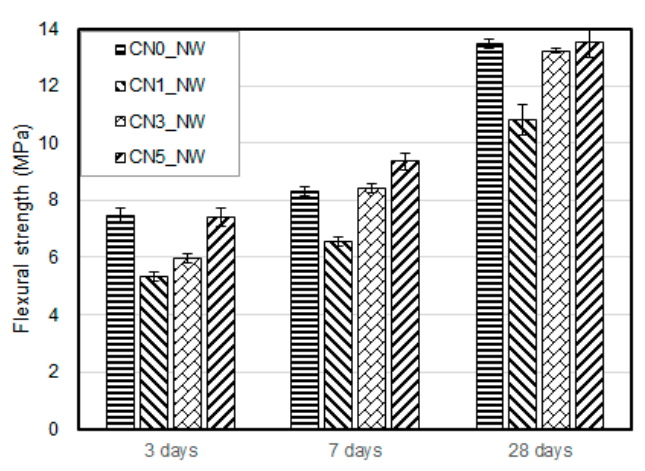

(b)

Figure 6. Flexural strength test results: (a) result with tap water; (b) result with nanobubble water.

This indicated that a certain strength improvement effect can be expected if the $\mathrm{CO}_{2}$ nanobubble water and calcium nitrite contents are properly adjusted in consideration of site conditions at the time of the section restoration.

\subsection{Length Change Rate}

Figure 7 shows the length change rate measurement results of specimens that used tap water and $\mathrm{CO}_{2}$ nanobubble water according to the calcium nitrite content and age. As the age increased, the shrinkage also increased owing to drying and the rapid hydration reaction at early ages. 
For tap water, the length change rate was higher with calcium nitrite contents of $1 \%$ or $3 \%$ than with contents of $0 \%$ or $5 \%$. For $\mathrm{CO}_{2}$ nanobubble water, the length change rate decreased with calcium nitrite contents of $3 \%$ or higher. In particular, for calcium nitrite contents of $5 \%$ or higher, the length change rate decreased sharply regardless of the type of mixing water used. A shrinkage reduction effect of $0.05-0.08 \%$ was confirmed at 56 days of age compared to the specimen without calcium nitrite.

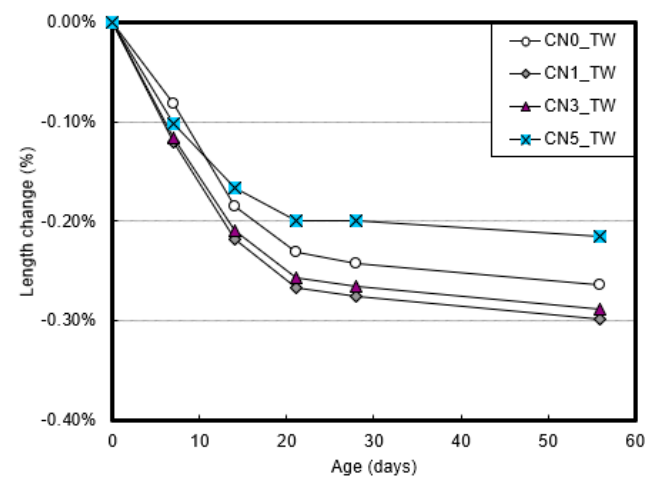

(a)

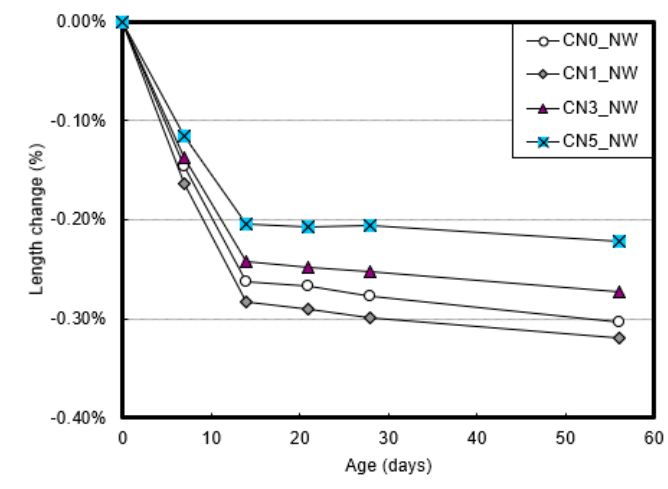

(b)

Figure 7. Length change rate of mortar: (a) result with tap water; (b) result with nanobubble water.

\subsection{Carbonation Depth}

Figure 8 shows the carbonation depth measurement results of specimens that used tap water and $\mathrm{CO}_{2}$ nanobubble water according to the calcium nitrite content. With both types of mixing water, the carbonation depth decreased as the calcium nitrite content increased.

As mentioned in Section 3.2, this appears to be because the internal structure became denser with increasing calcium nitrite content as nitrite-based hydration products increased and, in particular, a large amount of ettringite was generated owing to the accelerated reaction between $\mathrm{C}_{3} \mathrm{~A}\left(\mathrm{Al}_{2} \mathrm{O}_{3}\right)$ in cement and the $\mathrm{NO}_{2}{ }^{-}$ions in calcium nitrite. In particular, when $\mathrm{CO}_{2}$ nanobubble water was used, an accelerated reaction occurred between the $\mathrm{CO}_{3}{ }^{2-}$ ions in $\mathrm{CO}_{2}$ nanobubble water and the $\mathrm{Ca}^{+}$ions in cement. Therefore, the supply of $\mathrm{CO}_{3}{ }^{2-}$ ions alone caused the carbonation reaction, thereby increasing the generation of $\mathrm{CaCO}_{3}$ in the specimen. As a result, $\mathrm{CO}_{2}$ nanobubble water has a higher carbonation suppression effect owing to the densification of the structure [28-30]. In particular, when 5\% calcium nitrite was added, the quality criterion of KS F 4042 [16] for the carbonation depth of polymer cement mortar for repairing concrete structures (less than $2 \mathrm{~mm}$ carbonation depth at four weeks of age) could be met.

This indicates that carbonation can be suppressed through the proper use of $\mathrm{CO}_{2}$ nanobubble water and calcium nitrite. Both are judged to be helpful in improving the performance of the section-restoration mortar via the densification of the structure of the cement matrix.

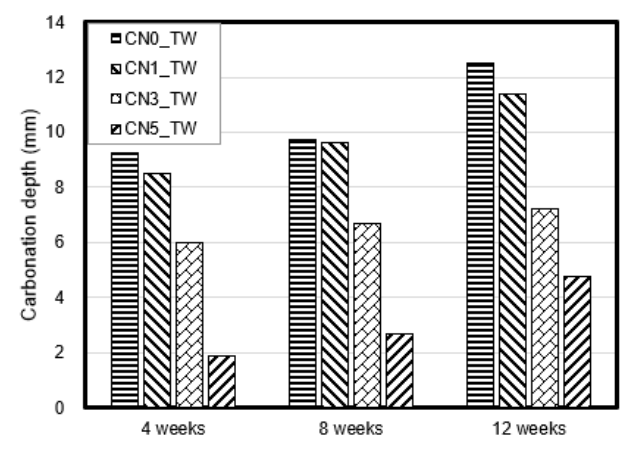

(a)

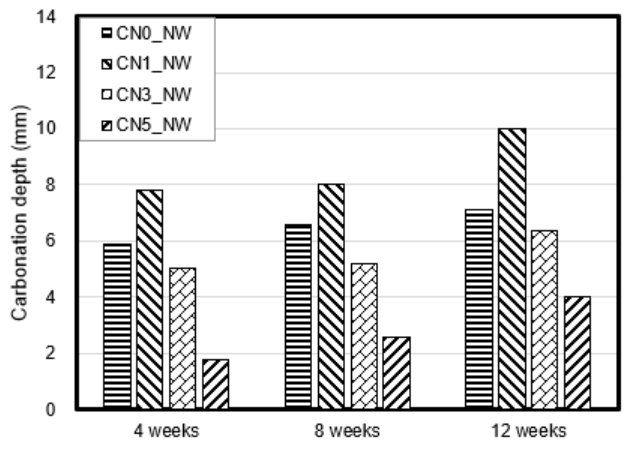

(b)

Figure 8. Carbonation depth: (a) result with tap water; (b) result with nanobubble water. 


\subsection{Porosity}

Figures 9 and 10 show the pore size distribution and cumulative pore volume results of specimens that used tap water and $\mathrm{CO}_{2}$ nanobubble water according to the calcium nitrite content and age. As the age increased, the cumulative pore volume decreased, indicating that the specimen structure became denser, thereby affecting the strength development. Overall, the addition of calcium nitrite slightly reduced the pore size and significantly reduced the cumulative pore volume.

In particular, when $\mathrm{CO}_{2}$ nanobubble water was used, the cumulative pore volume was smaller than with the use of tap water. This effect increased when calcium nitrite was used. As with strength development, this appears to be because the structure became denser through the accelerated reaction between $\mathrm{C}_{3} \mathrm{~A}\left(\mathrm{Al}_{2} \mathrm{O}_{3}\right)$ in cement and the $\mathrm{NO}_{2}{ }^{-}$ions in calcium nitrite as well as the reaction between the $\mathrm{CO}_{3}{ }^{2-}$ ions in $\mathrm{CO}_{2}$ nanobubble water and the $\mathrm{Ca}^{+}$ions in cement. In addition, it is judged as a result of reducing the pore volume and size due to the formation of carbonate in the pores by the reaction between the water and the $\mathrm{CO}_{3}{ }^{2-}$ ions inside the pores [31-33].

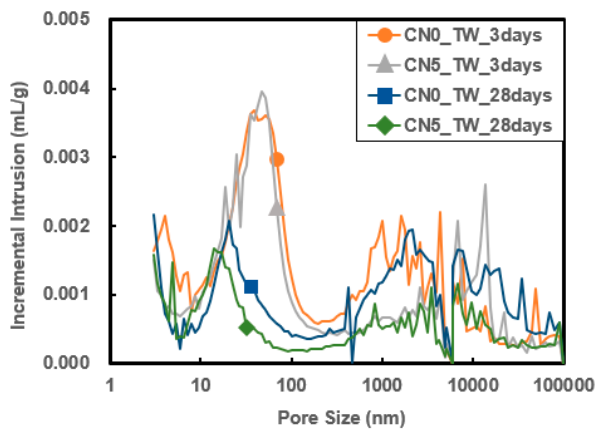

(a)

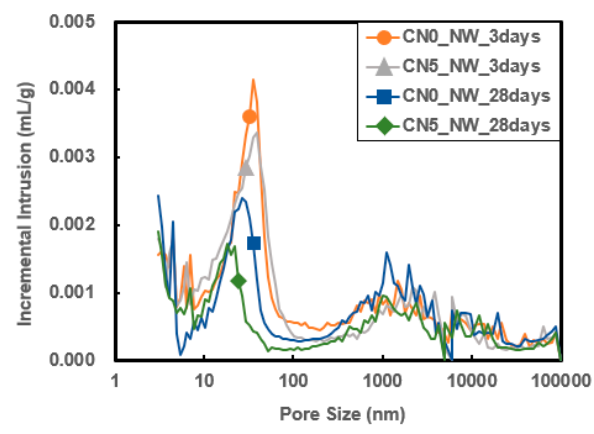

(b)

Figure 9. Incremental intrusion results: (a) result with tap water; (b) result with nanobubble water.

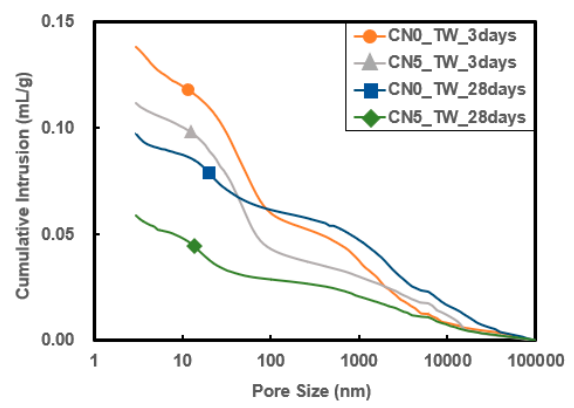

(a)

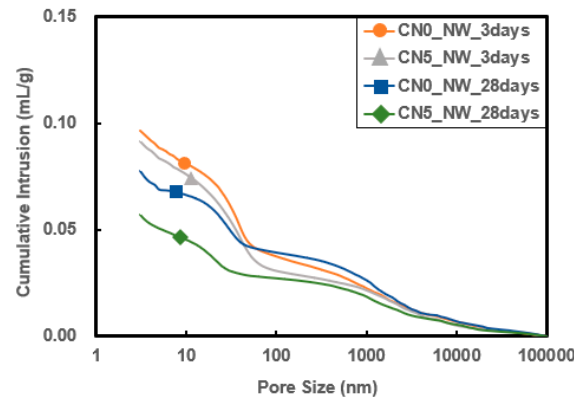

(b)

Figure 10. Cumulative intrusion results: (a) result with tap water; (b) result with nanobubble water.

\subsection{SEM}

Figure 11 shows the SEM observation results of specimens that used tap water and $\mathrm{CO}_{2}$ nanobubble water according to the calcium nitrite content. Each hydration product was estimated by comparing the crystal structures obtained in this study with the crystal forms and sizes of hydration products confirmed in previous studies.

As the age increased, a wider distribution of hydration products, such as C-S- $\mathrm{H}$ gel and $\mathrm{Ca}(\mathrm{OH})_{2}$, was observed. In the case of the specimens without calcium nitrite, ettringite with its acicular brittle fracture behavior was distributed with monosulfate at an early age. In the case of the specimens with calcium nitrite, monosulfate was partially observed along with sulfuric acid $\left(\mathrm{SO}_{4}{ }^{2-}\right)$-based ettringite on the $\mathrm{C}_{3} \mathrm{~A}$ surface of cement. Meanwhile, calcite was partially observed in the specimens that used $\mathrm{CO}_{2}$ nanobubble water containing $\mathrm{CO}_{3}{ }^{2-}$ ions. It appeared that $\mathrm{CaCO}_{3}$ (mainly calcite) was observed because the addition of calcium nitrite increased the generation rate of $\mathrm{C}-\mathrm{S}-\mathrm{H}$ gel and $\mathrm{Ca}(\mathrm{OH})_{2}$, and the 
$\mathrm{CO}_{3}{ }^{2-}$ ions in $\mathrm{CO}_{2}$ nanobubble water were adsorbed on the $\mathrm{Ca}^{2+}$ ions in the generated hydration products. In particular, nitrite-based hydration products and calcite-based $\mathrm{CaCO}_{3}$ were generated in large quantities in the specimens that used calcium nitrite and $\mathrm{CO}_{2}$ nanobubble water, indicating that the physical performance was improved through the densification of the structure.

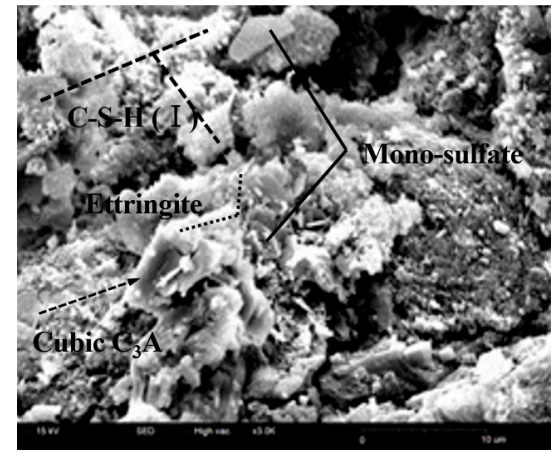

CN0 TW 3days

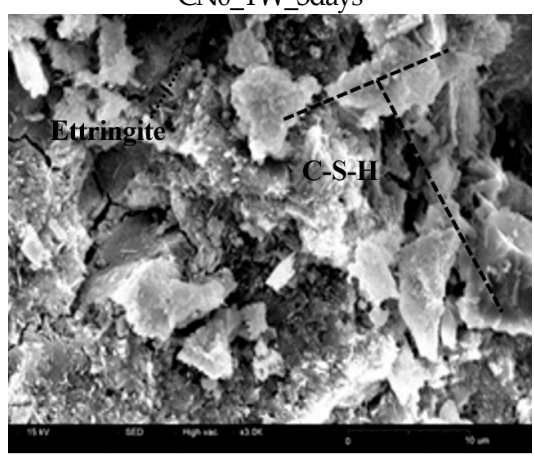

CN0_TW_28days
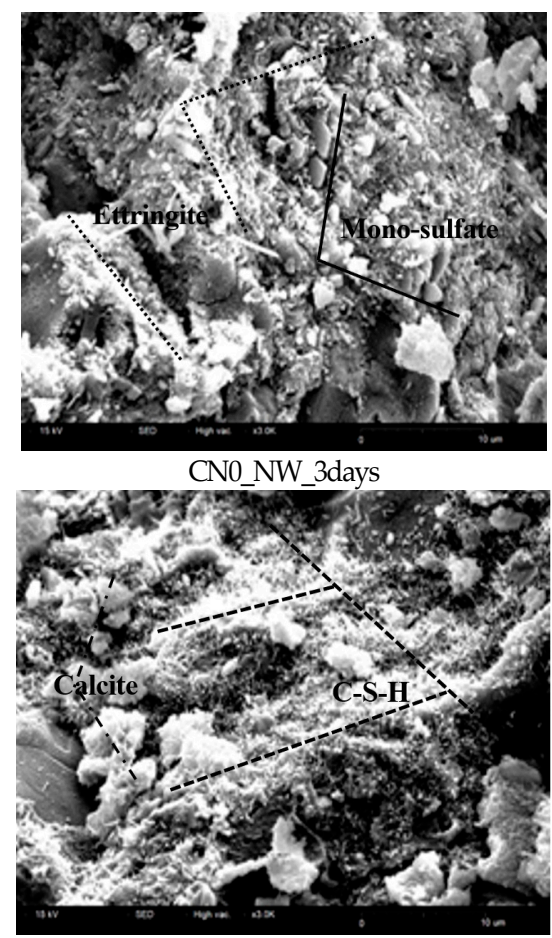

CN0_NW_28days

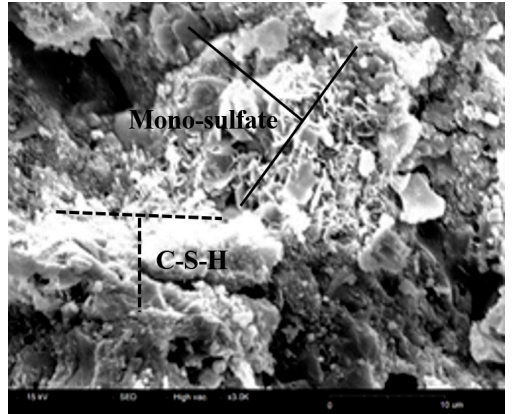

CN5 TW 3days

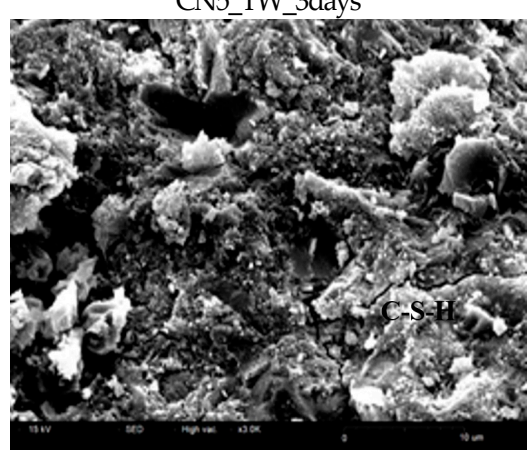

CN5_TW_28days

(a)
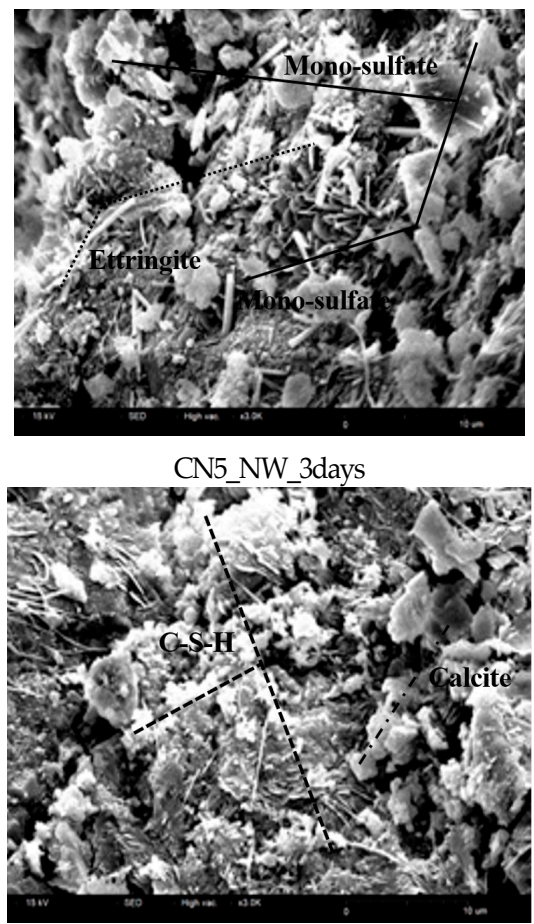

CN5_NW_28days

(b)

Figure 11. SEM $(3000 \times$ magnification): $($ a) result with tap water; $(\mathbf{b})$ result with nanobubble water. 


\section{Conclusions}

In this study, the physical properties of section-restoration mortar using calcium nitrite and $\mathrm{CO}_{2}$ nanobubble water as mixing water were investigated. The following conclusions were derived:

1. The flow values of the specimens with calcium nitrite tended to be high. No special tendency according to the type of mixing water and the calcium nitrite content was seen. When $5 \%$ calcium nitrite was added, the length change rate sharply decreased.

2. As the calcium nitrite content increased, strength and durability also increased. In particular, the use of $\mathrm{CO}_{2}$ nanobubble water effectively increased the strength and reduced the carbonation depth and porosity.

3. As the calcium nitrite content increased, the generation rate and generated amount of nitrite-based hydration products increased owing to the rapid reaction between the $\mathrm{NO}_{2}{ }^{-}$ions in calcium nitrite and the $\mathrm{C}_{3} \mathrm{~A}\left(\mathrm{Al}_{2} \mathrm{O}_{3}\right)$ in cement.

4. A large amount of $\mathrm{Ca}^{2+}$ ions from $\mathrm{Ca}(\mathrm{OH})_{2}$ and $\mathrm{C}-\mathrm{S}-\mathrm{H}$ gel, which were generated through the accelerated reaction between calcium nitrite and cement, reacted with the $\mathrm{CO}_{3}{ }^{2-}$ ions in the $\mathrm{CO}_{2}$ nanobubble water, thereby increasing the generation of calcite-based $\mathrm{CaCO}_{3}$ in the cement matrix. This appears to have affected the strength development and durability improvement via the densification of the structure. The densification of the matrix appears to reduce the pore volume and affect strength development as well as durability improvement.

These results suggest that the performance of polymer cement mortar for repairing concrete structures can be improved if calcium nitrite and $\mathrm{CO}_{2}$ nanobubble water are properly combined and applied.

Author Contributions: Conceptualization, H.C. (Hyeonggil Choi) and H.C. (Heesup Choi); Methodology, H.C. (Hyeonggil Choi); Investigation, Resources, D.L.; Writing-original draft preparation, H.-j.K.; Writing-review and Editing, H.C. (Hyeonggil Choi); Supervision, H.C. (Heesup Choi); Visualization, B.L.; Funding acquisition, D.-E.L. All authors have read and agreed to the published version of the manuscript.

Funding: This work was supported by the National Research Foundation of Korea (NRF) grant funded by the Korea government (MSIT) (No. NRF-2018R1A5A1025137).

Conflicts of Interest: The authors declare no conflict of interest.

\section{References}

1. Cheng, C.C.; Pouffary, S.; Svenningsen, N.; Callaway, J.M. The Kyoto Protocol, the Clean Development Mechanism, and the Building and construction SECTOR: A Report Prepared for the UNEP Sustainable Buildings and Construction Initiative; UNEP. Division of Technology, Industry and Economics: Paris, France, 2008.

2. Choi, H.; Choi, H.; Inoue, M.; Sengoku, R. Control of the polymorphism of calcium carbonate produced by self-healing in the cracked part of cementitious materials. Appl. Sci. 2017, 7, 546. [CrossRef]

3. Otsuki, N.; Kamada, T.; Imamoto, K.; Osada, K. Practical Guideline for Investigation, Repair and Strengthening of Cracked Concrete Structure -2013-; Japan Concrete Institute: Tokyo, Japan, 2013. (In Japanese)

4. Jacobsen, S.; Marchand, J.; Boisvert, L. Effect of cracking and healing on chloride transport in OPC concrete. Cem. Concr. Res. 1996, 26, 869-881. [CrossRef]

5. Toledo Filho, R.D.; Ghavami, K.; Sanjuán, M.A.; England, G.L. Free. Restrained and drying shrinkage of cement mortar composites reinforced with vegetable fibres. Cem. Concr. Compos. 2005, 27, 537-546. [CrossRef]

6. Menon, R.R.; Luo, J.; Chen, X.; Zhou, H.; Liu, Z.; Zhou, G.; Zhang, N.; Jin, C. Screening of fungi for potential application of self-healing concrete. Sci. Rep. 2019, 9, 2075. [CrossRef] [PubMed]

7. Han, S.; Choi, E.K.; Park, W.; Yi, C.; Chung, N. Effectiveness of expanded clay as a bacteria carrier for self-healing concrete. Appl. Biol. Chem. 2019, 62, 19. [CrossRef]

8. Magaji, A.; Yakubu, M.; Wakawa, Y.M. A review paper on self healing concrete. Int. J. Eng. Sci. 2019, 8, 47-54.

9. Choi, Y.; Oh, S.; Kim, C.; Nam, E. A Study on Crack Healing Properties of Cement Composites Mixed with Self-healing Microcapsules. J. Korea Inst. Struct. Maint. Insp. 2020, 23, 113-121. 
10. Shin, D.; Muhammad, H.; Min, K.; Lee, K.; Lee, J. Evaluation of Self-Healing Performance for Mortar Beams Containing Self-Healing Materials. J. Korea Inst. Struct. Maint. Insp. 2020, 24, 67-73.

11. Chen, H.J.; Peng, C.F.; Tang, C.W.; Chen, Y.T. Self-Healing Concrete by Biological Substrate. Materials 2019, 12, 4099. [CrossRef]

12. Xu, J.; Wang, X. Self-healing of concrete cracks by use of bacteria-containing low alkali cementitious material. Constr. Build. Mater. 2018, 167, 1-14. [CrossRef]

13. Palin, D.; Wiktor, V.; Jonkers, H.M. A bacteria-based self-healing cementitious composite for application in low-temperature marine environments. Biomimetics 2017, 2, 13. [CrossRef] [PubMed]

14. Edvardsen, C. Water permeability and autogenous healing of cracks in concrete. ACI Mater. J. 1999, 96, 448-454.

15. Ramachanran, V.S. Concrete Admixture Handbook; Noyes Publications: Park Ridge, NJ, USA, 1995; pp. 741-799.

16. Korean Industrial Standards. Polymer Modified Cement Mortar for Maintenance in Concrete Structure, KS F 4042; Korean Standards Association: Seoul, Korea, 2017.

17. Dockar, D.; Borg, M.; Reese, J. Mechanical stability of surface nanobubbles. Langmuir 2018, 35, 9325-9333. [CrossRef] [PubMed]

18. Guo, Z.; Wang, X.; Wang, H.; Hu, B.; Lei, Z.; Kobayashi, M.; Zhang, Z. Effects of nanobubble water on the growth of Lactobacillus acidophilus 1028 and its lactic acid production. RSC Adv. 2019, 9, 30760-30767. [CrossRef]

19. Takahashi, M.; Chiba, K.; Li, P. Free-radical generation from collapsing microbubbles in the absence of a dynamic stimulus. J. Phys. Chem. 2007, 111, 1343-1347. [CrossRef]

20. Korean Industrial Standards. Flow Table for Use in Test of Hydraulic Cement; KS L 5111; Korean Standards Association: Seoul, Korea, 2017.

21. Korean Industrial Standards. Standard Test Method for Polymer-Modified CEment Mortar; KS F 2476; Korean Standards Association: Seoul, Korea, 2019.

22. Korean Industrial Standards. Standard Test Method for Flexural Strength of Concrete; KS F 2408; Korean Standards Association: Seoul, Korea, 2016.

23. Korean Industrial Standards. Standard Test Method for Compressive Strength of Concrete; KS F 2405; Korean Standards Association: Seoul, Korea, 2017.

24. Korean Industrial Standards. Standard Test Method for Length Change of Mortar and Concrete; KS F 2424; Korean Standards Association: Seoul, Korea, 2015.

25. Korean Industrial Standards. Method for Measuring Carbonation Depth of Concrete; KS F 2596; Korean Standards Association: Seoul, Korea, 2004.

26. Choi, H.; Inoue, M.; Choi, H.; Kim, J.; Sudoh, Y.; Kwon, S.; Yoneyama, A. Physicochemical study on the strength development characteristics of cold weather concrete using a nitrite-nitrate based accelerator. Materials 2019, 12, 2706. [CrossRef]

27. Han, J.G.; Lee, S.H.; Na, J.J.; Hong, G.G.; Lee, J.H.; Kim, J.M. Effect of nano-bubble water for the compressive strength of cement mortar using in pile foundation. Korean Soc. Civil. Eng. 2012, 10, 1090-1093.

28. Choi, H.; Inoue, M. Self-healing of hardened cement paste affected by additional $\mathrm{Ca}^{2+}$ and $\mathrm{CO}_{3}{ }^{2-}$ ions with temperature control. J. Mater. 2020, 13, 012022.

29. Lee, S.; Kim, H.; Lim, Y.; Kim, D.; Park, B. Effect of $\mathrm{Na}_{2} \mathrm{SO}_{4}$ on autogenous healing in initial cracking of blast furnace slag cement paste. J. Korea Concr. Inst. 2019, 31, 261-267. [CrossRef]

30. Lee, W.; Lee, H.; Ahn, S.; Lee, K. Influence of Exposure Environmental Conditions on the Crack Healing Performance of Self-healing Repair Mortar Specimens. J. Korean Recycl. Constr. Resour. Inst. 2018, 6, $283-288$.

31. Chen, Z.; Lee, H. Physicochemical Properties of Cement Paste Containing $\mathrm{Mg}(\mathrm{OH})_{2} \mathrm{Cured}$ by $\mathrm{CO}_{2}$ curing Method. J. Korea Inst. Build. Constr. 2018, 18, 203-210.

32. Wu, B.; Ye, G. Development of porosity of cement paste blended with supplementary cementitious materials after carbonation. Constr. Build. Mater. 2017, 145, 52-61. [CrossRef]

33. Ashraf, W. Carbonation of cement-based materials: Challenges and opportunities. Constr. Build. Mater. 2016, 120, 558-570. [CrossRef]

(C) 2020 by the authors. Licensee MDPI, Basel, Switzerland. This article is an open access article distributed under the terms and conditions of the Creative Commons Attribution (CC BY) license (http://creativecommons.org/licenses/by/4.0/). 